\title{
The effect of a modified alarm medicine box in HIV patients undergoing antiretroviral therapy
}

\author{
Ramdan P. Ramdan, Bagus W. Bagus
}

Universitas Negeri Jakarta, Indonesia

\begin{abstract}
Introduction: Increased human immunodeficiency virus (HIV) and acquired immune deficiency syndrome (AIDS) cases in Indonesia create a new social problem, which must be followed up immediately. In this study, we created a modified alarm medicine box that can help HIV patients undergoing antiretroviral therapy (ART). We hope this tool will assist HIV patients in remembering to take their antiretroviral drugs. Aim of the study was to know the effect of a modified alarm medicine box, as a tool to assist HIV patients undergoing ART.

Material and methods: The study employed a quasi-experimental. We used a one-group, pre-test/ post-test design to determine the effect of the independent and dependent variables. In this study, we created a tool that can help HIV patients undergoing ART. We distributed the tool to $20 \mathrm{HIV}$ patients at the Yayasan Lentera Pelangi Jakarta foundation. The purpose of this tool is to reduce the risk of delay of ART in HIV patients. We recorded the time difference between before and after the usage of this tool, which was employed for seven days. In addition, we also provided a time report to be completed by the participants as they used the tool.

Results: The delivered range of mean values of the results obtained on the test before using the modified alarm medicine box was 20.76 , while after using the tool it was 2.81 . From the results of the data analysis obtained by calculating the difference in means $\left(17.94 M_{D}\right)$, and a standard deviation of difference $\left(16.06 S D_{D}\right)$, the standard error average difference was $3.68\left(S E_{M D}\right)$. In the next calculation, the $t$-count value was 4.875 , and the $t$-table value (with degrees of freedom $(n-1)$ and the error rate was $\alpha=0.05$ ) was 2.09. The means $t$-count $=4.875$ was larger than the $t$-table 2.09 . This shows that the null hypothesis $\left(H_{0}\right)$ could be rejected and the alternative hypothesis $\left(H_{1}\right)$ could be accepted. Therefore, the calculation results showed that the use of a modified alarm medicine box helped the patients undergoing ARV therapy to take their medicine on time.

Conclusions: The modified alarm medicine box helped the HIV patients in ART. Moreover, it was found that there was a decrease in the amount of delays in taking the drugs after using this tool.
\end{abstract}

HIV AIDS Rev 2018; 17, 1: 24-29 DOI: https://doi.org/10.5114/hivar.2018.73677

Key words: modified alarm medicine box, HIV patients, ART, drug resistance.

Address for correspondence: Dr. Bagus W. Bagus,
Universitas Negeri Jakarta, Indonesia,

e-mail: fransiskusasisibaguswinata@gmail.com
Article history:

Received: 22.10 .2017

Received in revised form: 02.11.2017

Accepted: 11.12.2017

Available online: 19.01.2018
International Journal of HIV-Related Problems

HIV \& AIDS

R e vi e w 


\section{Introduction}

The numbers of people with human immunodeficiency virus (HIV) and acquired immune deficiency syndrome (AIDS) have been increasing in recent decades. In addition, there are still more people who have contracted HIV or AIDS, but are not yet aware of illness. Of course, this lack of awareness increases the quantity of HIV sufferers every year. Furthermore, the age range of HIV sufferers has expanded from adults between 26-35 years to adolescents as young as 12-years-old.

Various efforts have been made by the government and community volunteers to reduce the scope and impact of the virus. One of the government's roles is to subcontract medicines for those already infected with HIV or AIDS. Because of this program, some positive effects have occurred for people with HIV, such as being able to enjoy their lives again, even though they must consume drugs on a daily basis. These drugs are expected to slow down or prevent HIV virus to transform into AIDS [1].

Although the government treatment program for patients with HIV and AIDS is a step in the right direction, the struggle to liberate Indonesia from the HIV virus does not stop there. In fact, there are still many problems with the program, such as inability or consistency of many patients to take their medicine on time. Moreover, many patients still lead an unhealthy lifestyle that may contribute to worsening their overall health condition. The very rapid process of the development of the virus in human body and its spread to other people in Indonesia, has become a significant challenge in the country.

Based on data released in a Ministry of Health report "The Situation of HIV-AIDS Problem 1987-September 2014", during this period, HIV/AIDS has spread to 381 (76\%) of the 498 districts of Indonesia. The province of Bali was the first in Indonesia to discover the presence of HIV/ AIDS, while the last province to report its presence was West Sulawesi in 2011.

Until 2000, the number of reported HIV cases was 859 . In 2006, the number of newly reported HIV cases rose to 7,195 and in 2014, it reached the amount of 22,869 cases.

The cumulative number of HIV infections in Indonesia was reported up to September 2014 as 150,296 cases. Areas with the highest numbers of reported HIV infections in 2014 were Jakarta $(32,782)$, followed by East Java $(19,249)$, Papua $(16,051)$, West Java $(13,507)$, and Bali (9.637) [2] .

Until 2005, the number of reported AIDS cases was 5,184 . In 2006, the number of AIDS cases rose to 3,665. By 2011 , this number reached 7,312 cases, finally falling to 1,876 cases in 2014. The cumulative number of AIDS cases from 1987 to September 2014 was 55,799, with the highest number of cases of HIV and AIDS occurring in Jakarta. This rise is connected to changing lifestyles in Jakarta, including an increase in homosexual activity and its associated risks for the spread of HIV and AIDS between sexual partners. However, those at risk for HIV and AIDS transmission in
Indonesia also include heterosexuals, recipients of blood transfusions, babies through perinatal transmission, injection drug users, etc. However, the situation in Indonesia still requires further investigation and analysis [3].

\section{HIV/AIDS}

Many people are still not aware of the difference between HIV and AIDS, with many believing that the two are the same. HIV is a virus that attacks the body's immune system, causing the body to become weak as it fights off infection [4]. As a result of the body's weakened immune system, other viruses or so-called opportunistic diseases can attack the body [5].

Without a treatment, a person with HIV can survive for 9 to 11 years after acquiring the infection. In other words, the presence of this virus in the body will cause immune system deficiency. Transmission of the HIV virus can occur through the exchange of bodily fluids such as semen, blood, vaginal fluid, and breast milk. Furthermore, HIV weakens the body by killing important cells, such as helper T cells, macrophage, and dendritic cells [6].

\section{ARV therapy}

ARV drugs are taken to slow dawn the progression of the HIV virus in the body. ARV drugs must be taken by HIV patients on a daily basis for their entire lives [7]. Termination of drugs in the treatment process poses a new problem for HIV sufferers. Unfortunately, the side effects of the ARV drugs can discourage patients from taking their medicines [8]. Because of unpleasant side effects caused by the ARV drugs, HIV patients can become reluctant to take the medications regularly [9]. Many patients also stop taking their ARV drugs, when their health condition improves. However, irregularity in taking antiretroviral drugs or their complete rejection can cause patients' health to deteriorate. Once the virus becomes immune to first-line ARV, a drug resistance can occur, which requires the patient to take second-line ARV drugs that are more expensive [10].

\section{Accuracy of antiretroviral therapy}

ARV therapy or antiretroviral drugs are anti-HIV drugs that can suppress the development of HIV in the body. Some commonly used ARVs in Indonesia include durival and neviral. All patients diagnosed with HIV need to begin ARV therapy immediately [11]. Moreover, the use of ARV drugs should be directed by a physician. ARV therapy serves to suppress the proliferation of HIV rather than curing the infection. Therefore, ARV therapy should be continued daily for the entire life. If ARV therapy is stopped, HIV will spread and increase in the blood. Furthermore, cessation of antiretroviral drug consumption in HIV patients puts them at the risk of viral resistance to ARV drugs [12]. 


\section{The essence of the modified alarm medicine box}

This study examined the use of a modified alarm medicine box to remind HIV sufferers to take their ARV drugs during antiretroviral therapy in a proper manner. There are two important functions of this device:

- a reminder alarm that sounds every 12 hours,

- a storage compartment for ARV pills.

The concept of the modified alarm medicine box to improve the accuracy of ARV therapy for HIV and AIDS sufferers is actually very simple. As a reminder for people with HIV to take medication every 12 hours, this tool assists HIV patients in remembering to take their antiretroviral drugs. Because the alarm box has been modified to contain a small box of ARV drugs, not only can it provide a place to store ARV drugs, but also it can be taken with patients anywhere.

The modified alarm box will thus hopefully assist HIV patients in remembering to take their ARV drugs every 12 hours, which in turn will prevent the development of viral resistance to ARV drugs. The modified alarm box displayed in Figure 1.

\section{Material and methods}

The research method used in the present study was a quasi-experimental, one-group pre-test/post-test design to investigate the effect of the independent and dependent variables. The independent variable was the patients' timeliness in taking the ARV therapy drugs, while the dependent variable was the modified alarm box [13].

Each participant's medical history and records were examined prior participating in the study. The research design can be illustrated in Figure 2 .

In the present study, the entire population was the subject of the study, including children and adults (both male and female) with HIV and AIDS receiving treatment at the Yayasan Lentera Pelangi Jakarta Foundation. A total of 20 out of 40 patients from the foundation participated in this study [14].

The study sample was a partial or representative sample of the population under study. The results of sample research should be generalizable to the target population [15], as applying the research conclusions to the entire population [16]. The present study used a purposive sampling technique, based on the following patient characteristics:

- confirmed HIV/AIDS positive status,

- aged between 15-30 years,

- under antiretroviral therapy (ARV),

- willing to participate in the study for seven days and fill out the time report.

On the other hand, participants were excluded from the research based on the following criteria:

- no compliance with the exercise guidelines or using the modified alarm box at the specified times,

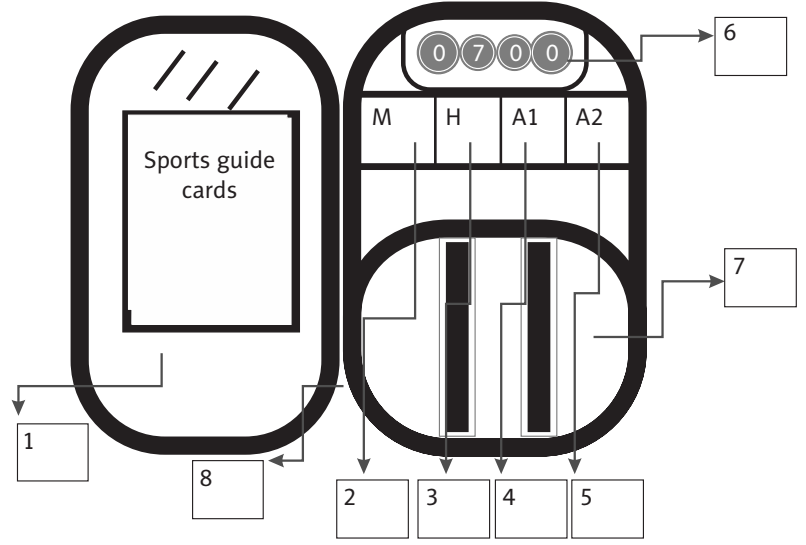

Explanation Figure:

1. Sports guide cards, as a supporting feature of this tool.

2. Memo button, the button is one device part of the four devices to set the alarm box.

3. Hour button, the button is the device key to set the time, especially in adjusting the clock.

4. Alarm 1 button, the button is the device key to set the time, especially in set minutes.

5. Alarm 2 button, the button is the device key to set the dead or live alarm rings.

6. Digital numbers to see the time or hours.

7. Box baffle device, which is useful for storing PIL ARV safely and efficiently.

8. Box cover device or a box cover cover, which is useful for keeping the PIL ARV safe in the box.

Figure 1. The modified alarm box

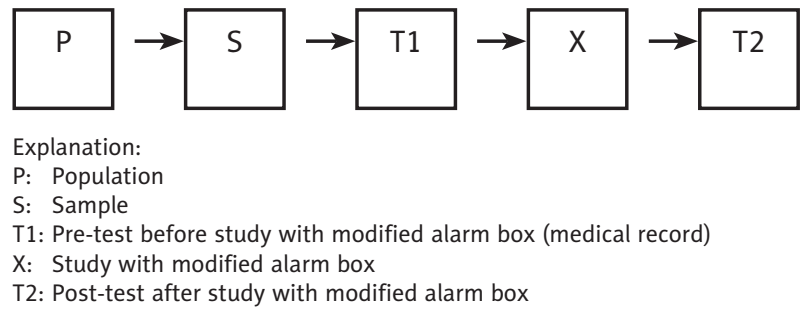

Figure 2. The research design

- lack of usage of the modified alarm box due to malfunctioning of the alarm box itself.

In accordance with the research hypothesis and data analysis techniques used, the statistical hypothesis illustrates as follows:

- $\mathrm{H} 0: \beta \mathrm{y} 1 \leq 0$,

- $\mathrm{H} 1: \beta y 1>0$.

\section{Results}

The present study is based on the timeliness of HIV patients taking ARV therapy drugs (X) using a modified alarm box (Y).

\section{Data}

The data described below are intended to provide an overview of the analyses, which includes the lowest values, highest values, means, standard deviations, standard errors, frequency distributions, and histograms of each variable. 
Table 1. Frequency distribution before using modified alarm box

\begin{tabular}{l|c|c|c|c}
\hline No. & Interval class & Midpoint & Frequency & $\begin{array}{c}\text { Percentage } \\
(\%)\end{array}$ \\
\hline 1 & $0-12.15$ & 6.075 & 6 & 30 \\
\hline 2 & $12.16-24.31$ & 18.235 & 9 & 45 \\
\hline 3 & $24.32-36.47$ & 30.395 & 2 & 10 \\
\hline 4 & $36.48-48.63$ & 42.555 & 1 & 5 \\
\hline 5 & $48.64-60.79$ & 54.715 & 1 & 5 \\
\hline 6 & $60.80-72.95$ & 66.875 & 1 & 5 \\
\hline \multicolumn{2}{l|}{ Total } & & 20 & 100 \\
\hline
\end{tabular}

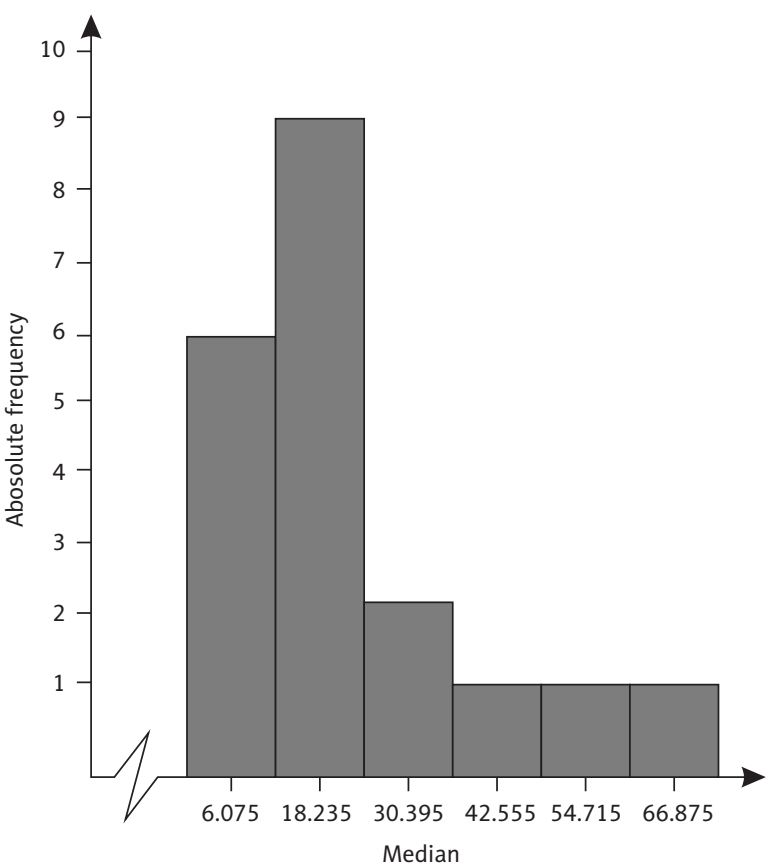

Figure 3. Chart of frequency distribution before using modified alarm box

During this research, the results were differentiated according to two variables: before using the modified alarm box and after using the modified alarm box. The data of before using the modified alarm box had the following values: highest value $(64,285$ minutes), lowest value ( 0 minutes), average value (20.76 minutes until a week), standard deviation (16.9), and standard error (3.87). In addition, the data of after using the modified alarm box had the following values: highest value ( 8,857 minutes), lowest value ( 0 minutes), average value (2.81 minutes until a week), standard deviation (2.23), and standard error (0.511).

\section{Data of test results before using the modified alarm box}

The data obtained from the initial test had a time range of 64,285 to 0 , and obtained an average of 20.76 with a standard deviation of 16.9 , and standard error of 3.87 . This is
Table 2. Frequency distribution after using modified alarm box

\begin{tabular}{l|c|c|c|c}
\hline No. & Interval class & Midpoint & Frequency & $\begin{array}{c}\text { Percentage } \\
\text { (\%) }\end{array}$ \\
\hline 1 & $0-1.67$ & 0.835 & 7 & 35 \\
\hline 2 & $1.68-3.35$ & 2.515 & 6 & 30 \\
\hline 3 & $3.36-5.03$ & 4.195 & 5 & 25 \\
\hline 4 & $5.04-6.71$ & 5.875 & 1 & 5 \\
\hline
\end{tabular}

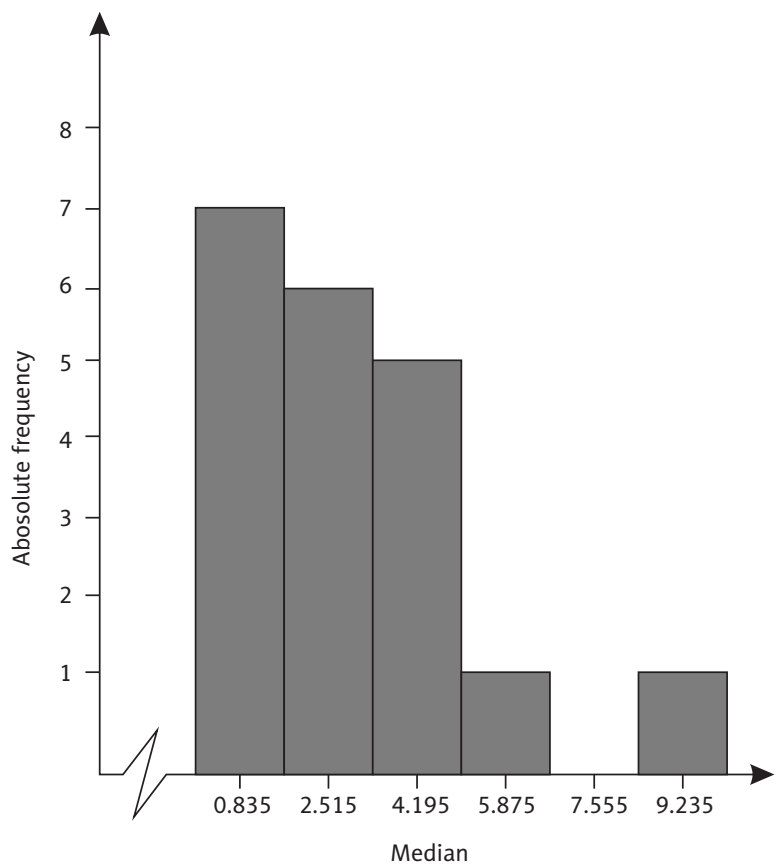

Figure 4. Chart of frequency distribution after using modified alarm box

shown in the frequency distributions displayed in Table 1 and Figure 3.

\section{Data test results after using the modified alarm box}

The data obtained from the final test had a time range of 0 to 8,857 , obtained an average of 2.81 with a standard deviation of 2.23, and a standard error of 0.511 . This is shown in the distributions displayed in Table 2 and Figure 4.

\section{Statistical hypotheses testing}

The delivered range of mean values of the results obtained from the test before using the modified alarm box was 20.76, while the range after using the modified alarm box was 2.81 . From the results of the data analysis obtained by calculating the difference in means $\left(M_{D}\right) 17.94$, with a stan- 
Table 3. Data from before and after using modified alarm medicine box (average of seven days)

\begin{tabular}{|c|c|c|c|c|}
\hline No & $\begin{array}{l}\text { Initial } \\
\text { name }\end{array}$ & Sex & $\begin{array}{c}\text { Time before } \\
\text { using } \\
\text { (minutes) }\end{array}$ & $\begin{array}{c}\text { Time after } \\
\text { using } \\
\text { (minutes) }\end{array}$ \\
\hline 1 & $\mathrm{~T}$ & Female & 22.14 & 2.14 \\
\hline 2 & P.S. & Male & 30.00 & 2.00 \\
\hline 3 & A & Female & 15.00 & 1.28 \\
\hline 4 & A & Female & 23.14 & 4.28 \\
\hline 5 & $R$ & Male & 12.85 & 1.42 \\
\hline 6 & $\mathrm{R}$ & Female & 64.28 & 2.14 \\
\hline 7 & D & Female & 50.71 & 5.00 \\
\hline 8 & $R$ & Male & 0 & 0 \\
\hline 9 & $\mathrm{~N}$ & Female & 0 & 0 \\
\hline 10 & 1 & Male & 5.00 & 2.14 \\
\hline 11 & W & Female & 22.85 & 8.85 \\
\hline 12 & $S$ & Female & 42.85 & 1.42 \\
\hline 13 & $Y$ & Female & 34.28 & 2.14 \\
\hline 14 & $\mathrm{H}$ & Male & 20.00 & 3.57 \\
\hline 15 & $\mathrm{~F}$ & Male & 15.00 & 6.42 \\
\hline 16 & I.A. & Male & 20.71 & 5.00 \\
\hline 17 & G & Male & 6.42 & 2.14 \\
\hline 18 & $S$ & Male & 4.28 & 1.42 \\
\hline 19 & A & Male & 9.28 & 0.71 \\
\hline 20 & B & Male & 16.42 & 4.28 \\
\hline
\end{tabular}

dard deviation difference of $\left(S D_{D}\right) 16.06$, the difference in the standard error average was $\left(S E_{M D}\right) 3.68$. In the next calculation, the $\mathrm{t}$-count value was 4.875 , the $\mathrm{t}$-table value with degrees of freedom $(n-1)$, and the error rate of $\alpha=0.05$ was 2.09. The means the $t$-count of 4.875 was larger than the $\mathrm{t}$-table value of 2.09. Thus, the null hypothesis $\left(H_{0}\right)$ was rejected, and the alternative hypothesis $\left(H_{1}\right)$ was accepted. Therefore, the calculation results show that the use of the modified alarm box positively affected the patients' timeliness of taking the ARV therapy drugs.

\section{Discussion}

Based on the data analysis, it was found that the hypotheses could be accepted. This means that using the modified alarm box had a significant effect on the patients who were able to take their ARV drugs on time. The study findings also showed a positive effect on the motivation of HIV patients to live a healthy lifestyle. It was found that by using this tool, a decreased level of delays in taking ARV medication has occurred, as evidenced by the coefficient value after using the modified alarm box at an average value of 2.81 . This is considerably lower rate than the value before using the modified alarm box at an average value of 20.76.
Table 4. Research data influence of modified alarm box, average, standard deviation, standard error, before and after using the alarm box

\begin{tabular}{|c|c|c|c|c|c|}
\hline (x) & (y) & $(x-X)$ & $(y-x)$ & $(x-x)^{2}$ & $(y-x)^{2}$ \\
\hline 22.14 & 2.14 & 1.38 & -0.67 & 1.9044 & 0.4489 \\
\hline 30 & 2 & 9.24 & -0.81 & 85.3776 & 0.6561 \\
\hline 15 & 1.28 & -5.76 & -1.53 & 33.1776 & 2.3409 \\
\hline 23.14 & 4.28 & 2.38 & 1.47 & 5.6644 & 2.1609 \\
\hline 12.85 & 1.42 & -7.91 & -1.39 & 62.5681 & 1.9321 \\
\hline 64.28 & 2.14 & 43.52 & -0.67 & $1,893.9904$ & 0.4489 \\
\hline 50.71 & 5 & 29.95 & 2.19 & 897.0025 & 4.7961 \\
\hline 0 & 0 & -20.76 & -2.81 & 430.9776 & 7.8961 \\
\hline 0 & 0 & -20.76 & -2.81 & 430.9776 & 7.8961 \\
\hline 5 & 2.14 & -15.76 & -0.67 & 248.3776 & 0.4489 \\
\hline 22.85 & 8.85 & 2.09 & 6.04 & 4.3681 & 36.4816 \\
\hline 42.85 & 1.42 & 22.09 & -1.39 & 487.9681 & 1.9321 \\
\hline 34.28 & 2.14 & 13.52 & -0.67 & 182.7904 & 0.4489 \\
\hline 20 & 3.57 & -0.76 & 0.76 & 0.5776 & 0.5776 \\
\hline 15 & 6.42 & -5.76 & 3.61 & 33.1776 & 13.0321 \\
\hline 20.71 & 5 & -0.05 & 2.19 & 0.0025 & 4.7961 \\
\hline 6.42 & 2.14 & -14.34 & -0.67 & 205.6356 & 0.4489 \\
\hline 4.28 & 1.42 & -16.48 & -1.39 & 271.5904 & 1.9321 \\
\hline 9.28 & 0.71 & -11.48 & -2.1 & 131.7904 & 4.41 \\
\hline 16.42 & 4.28 & -4.34 & 1.47 & 18.8356 & 2.1609 \\
\hline$\Sigma$ & 415.21 & 56.35 & & & \\
\hline$\chi$ & 20.76 & 2.81 & & & \\
\hline SD & 16.9 & 2.23 & & & \\
\hline $\mathrm{SE}_{\mathrm{MD}}$ & 3.87 & 0.511 & & & \\
\hline
\end{tabular}

\section{Conclusions}

After analyzing the data, it can be concluded that the use of the modified alarm box had a direct effect on the timeliness of the patients' consumption of their ARV medication. This means that, if this tool can be developed and distributed to patients, it can reduce or resolve the problem of viral drug resistance.

\section{Practical implications}

1. The modified alarm medicine box can serve as a tool to facilitate ARV therapy for HIV patients in a timely manner.

2. The modified alarm medicine box can serve as a tool to prevent viral resistance among HIV patients.

\section{Acknowledgments}

The authors would like to thank Yayasan Lentera Pelangi Jakarta for providing data for this study. No financial support was required or provided for this study. 
Table 5. Before and after tests using modified alarm box for t-test count

\begin{tabular}{|c|c|c|c|c|}
\hline No & Before (x) & After (y) & $D=(y-x)$ & $D^{2}$ \\
\hline 1 & 22.14 & 2.14 & -20 & 400 \\
\hline 2 & 30 & 2 & -28 & 784 \\
\hline 3 & 15 & 1.28 & -13.72 & 188.2384 \\
\hline 4 & 23.14 & 4.28 & -18.86 & 355.6996 \\
\hline 5 & 12.85 & 1.42 & -11.43 & 130.6449 \\
\hline 6 & 64.28 & 2.14 & -62.14 & $3,861.3796$ \\
\hline 7 & 50.71 & 5 & -45.71 & $2,089.4041$ \\
\hline 8 & 0 & 0 & 0 & 0 \\
\hline 9 & 0 & 0 & 0 & 0 \\
\hline 10 & 5 & 2.14 & -2.86 & 8.1796 \\
\hline 11 & 22.85 & 8.85 & -14 & 196 \\
\hline 12 & 42.85 & 1.42 & -41.43 & $1,716.4449$ \\
\hline 13 & 34.28 & 2.14 & -32.14 & $1,032.9796$ \\
\hline 14 & 20 & 3.57 & -16.43 & 269.9449 \\
\hline 15 & 15 & 6.42 & -8.58 & 73.6164 \\
\hline 16 & 20.71 & 5 & -15.71 & 246.8041 \\
\hline 17 & 6,42 & 2.14 & -4.28 & 18.3184 \\
\hline 18 & 4.28 & 1.42 & -2.86 & 8.1796 \\
\hline 19 & 9.28 & 0.71 & -8.57 & 73.4449 \\
\hline 20 & 16.42 & 4.28 & -12.14 & 147.3796 \\
\hline$\Sigma$ & 415.21 & 56.35 & -358.86 & $11,600.6586$ \\
\hline
\end{tabular}

\section{Conflict of interest}

The author's declared no potential conflicts of interest with respect to the research, authorship, and/or publication of this article.

\section{References}

1. Kim J, Jobe O, Peachman KK, et al. Quantitative analyses reveal distinct sensitivities of the capture of HIV-1 primary viruses and pseudoviruses to broadly neutralizing antibodies. Virology 2017; 508: 188-198.

2. Kesehatan K. Laporan Perkembangan HIV-AIDS Triwulan I Tahun. $1^{\text {st }}$ ed. Kemenkes RI, Jakarta 2016.

3. Connell BJ, Lortat-Jacob H. Human immunodeficiency virus and heparan sulfate: From attachment to entry inhibition. Front Immunol 2014; 20: 350-385.

4. Mohamad S, Deris ZZ, Yusoff NK, et al. Assessing subtypes and drug resistance mutations among HIV-1 infected children who failed antiretroviral therapy in Kelantan, Malaysia. Braz J Infect Dis 2012; 16: 284-288.

5. Chan P. State of the art on ARV therapy: How many standards of care? Int J Infect Dis 2010; 14: 315.

6. Marx JL. New disease baffles medical community. Science 1982; 217: 618-621

7. dos Santos IK, de Azevedo KPM, Silveira APFK, et al. Physical activity and sleep of persons living with HIV/AIDS: A systematic review. Rev Andal Med Deporte 2017; 10: 19-24.

8. Balisanga H, Mutagoma M, Remera E, et al. HIV surveillance in Rwanda: Readiness assessment to transition from antenatal care- based to prevention of mother-to-child transmission program-based HIV surveillance. Int J Infect Dis 2016; 52: 62-67.

9. Troncoso A. Will there be a cure for HIV/AIDS? Making the dream a reality. Asian Pacific Journal of Tropical Biomedicine 2016; 6: 441-442.

10. Dewi Rokhmah K. The role of sexual behaviour in the transmission of HIV and AIDS in adolescents in coastal areas. Journal of Procedia Environmental Science 2015; 23: 99-104.

11. Page J, Louw M, Pakkiri D. Working with HIV/AIDS. Juta Legal and Academic Publishers, Cape Town 2006.

12. Wammes JJ, Siregar AY, Hidayat T, et al. Cost-effectiveness of methadone maintenance therapy as HIV prevention in an Indonesian high-prevalence setting: A mathematical modeling study. Int J Drug Policy 2012; 23: 358-364.

13. Nguyen PA, Syed-Abdul S, Minamareddy P, et al. A method to manage and share anti-retroviral (ARV) therapy information of human immunodeficiency virus (HIV) patients in Vietnam. Computer Methods and Programs in Biomedicine 2013; 111: 290-299.

14. Anas S. Pengantar Statistik Pendidikan. Raja Grafindo Persada, Jakarta 2003.

15. Nasution S. Metode Research. Bumi Aksara, Jakarta 2007.

16. Arikunto S. Prosedur Penelitian. Rineka Cipta, 2010. 